2 Title:

3 The Production and Circulation of Indigenous Lead-Glazed Ceramics in Northern Peru

4 During Spanish Colonial Times

6 Authors:

7 Parker VanValkenburgh ${ }^{a^{*}}$

8 Sarah J. Kellowayb

9 Laure Dussubieuxc

10 Jeffrey Quilter

11 Michael D. Glascock

12

\title{
27 Abstract
}

${ }^{*}$ Corresponding Author. Tel+1 6178809294 Email parkervan@gmail.com

a Department of Anthropology, Brown University. Box 1921, Providence, Rhode Island 02912, U.S.A

b XRF Laboratory, Solid State and Elemental Analysis Unit, Mark Wainwright Analytical Centre, University of New South Wales, Chemical Sciences Building (F10), Kensington,2052, Australia

c Elemental Analysis Facility, The Field Museum, 1400 South Lake Shore Drive, Chicago, IL 60605 USA

d Peabody Museum of Archaeology and Ethnology, Harvard University 11 Divinity Avenue, Cambridge, MA 02138 USA

e Research Reactor Center, University of Missouri, Colombia, MO 65211 USA 
In this paper, we characterize the production and circulation of Early Green Glazed (EGG) Ware, an innovative variety of lead-glazed ceramics produced in Peru's North Coast region in the wake of the Spanish colonization of the Andes. INAA of pastes and LA-ICP-MS of glazes of EGG Ware samples collected from sites in Peru's Zaña, and Chicama river valleys reveal contrasting patterns of composition. While paste characterization via INAA identified a great deal of compositional diversity, LA-ICP-MS data from glazes falls into two discrete groups. We interpret these results as evidence of 1) disperse production of pastes, employing either a wide variety of source materials and/or recipes, mirroring the production of Late Preshispanic paddle-stamped wares, and 2) more nucleated collection of materials for glaze production, perhaps from distinct sources of lead ore. We interpret the presence of small numbers of samples with glaze compositions characteristic of the Zaña valley in Chicama Valley assemblages as evidence of possible trade between indigenous communities in artisanal goods and/or raw materials during the late 16 th century $\mathrm{CE}$.

\section{Keywords}

INAA, LA-ICP-MS, Cultural hybridity, technology transfer, ceramics, Peru

\section{Introduction}

During the $16^{\text {th }}$ century CE, potters living in what is now northern Peru produced a curious variety of ceramics - vessels with largely pre-Hispanic forms covered with a

61 lead glaze, a surface treatment that appeared in the Andes only after the Spanish

62 invasion of 1532 CE. Previous discussions of these vessels have seen them as icons of

63 the transformation of native craft and technology under Spanish rule (Acevedo Basurto

64 et al., 2004; Acevedo, 1986; Bushnell, 1959; Hecker and Hecker, 1988; Mayer, 1984; 
65 Mogrovejo Rosales, 1996). However, only recently have samples been recovered in

66 archaeological context, permitting discussions to push beyond general speculation

67 about where, when and how this pottery was produced and utilized. Some observers

68 have argued that such vessels were made by native artisans who learned glazing

69 techniques through explicit instruction from Spanish artisans (Bushnell, 1959; Mayer,

70 1984), while others have emphasized how they attest to the continuity of native ceramic

71 technologies during colonial times (Acevedo Basurto et al., 2004; Tschopik, 1950).

72 We label these ceramics Early Green Glazed (EGG) Ware, and argue that they

73 were produced by indigenous artisans who incorporated glazing into their existing

74 decorative programs in the $16^{\text {th }}$ century. Rather than being the products of one or two

75 workshops overseen by Spanish ceramicists, we argue that EGG Ware was produced

76 in dispersed locations, not unlike the paddle-stamped ceramics found in domestic

77 assemblages throughout much of the North Coast region since $1000 \mathrm{CE}$ (Cleland and

78 Shimada, 1998; VanValkenburgh, 2012, n.d.). The results of the analyses presented in

79 this study suggest that some North Coast potters incorporated glazing into their

80 decorative programs relatively quickly. At the same time, they likely obtained the lead

81 ores needed to produce glazes from a limited number of sources (perhaps two).

82 In this study, we present chemical characterization data of both glazes and

83 pastes of samples recovered from Peru's Zaña and Chicama valleys. The samples of

84 EGG Ware were collected from excavations at three sites - Carrizales (Zaña Valley),

85 Mocupe Viejo (Zaña Valley), and Magdalena de Cao Viejo (Chicama Valley), as well as

86 surface collections from three additional single-component sites in the lower Zaña valley

87 - Puerto de Chérrepe, Conjunto 216 and Conjunto 271 (Figure 1). Analysis of glaze 
88 composition suggests that the artisans who produced these materials used two distinct

89 lead ore sources, while the diversity of paste composition suggests that the type's

90 producers employed a variety of clay sources and/or paste recipes - a pattern that may

91 reflect their organization into dispersed workshops. Together, these results underscore

92 the socially and geographically complex nature of technological change in Spanish

93 colonial Peru.

94

95

[Insert Figure 1]

96

\section{2. Background}

98 2.1. Early Green Glazed Ware: Form, Context and Chronology

The glazed surfaces of EGG Ware vessels readily mark them as products of

100 artisans working after the Spanish invasion of the Americas. Current scholarly

101 consensus is that true glazes - thin layers of glass fused onto the surface of ceramics,

102 containing both silica and fluxes - were never produced by Prehispanic potters (Rice,

103 1987, p. 20). In isolated cases (particularly, the American southwest and Southern

104 Guatemala), ancient American ceramicists produced surface treatments with glassy

105 appearances, but compositional research suggests that these treatments are the

106 products of alternative technologies (Fenn et al., 2006; Habicht-Mauche, 2006;

107 Herhahn, 2006; Neff 2003; Neff and Bishop, 1988; Shepard, 1948; Van Keuren, 2006;

108 Van Keuren et al., 2013).

109 Among ceramics from Prehispanic South America, no similar examples of

110 "subglazes" or "pseudoglazes" are known. EGG Ware vessels held in museum 
111 collections, which are wholly covered with a thin yellowish to light green glaze underlain

112 by either buff-colored or grey-black paste, have therefore been interpreted as the

113 products of artisans working after the Spanish invasion of the Americas - most likely

114 following the first concerted wave of European colonization of Western South America

115 in $1532 \mathrm{CE}$. The majority of their forms are almost identical to ceramics of the Chimu-

116 Inka style - a short-lived artistic tradition believed to postdate the establishment of Inka

117 hegemony in the region, circa 1470-1532 C.E., and which we discuss in further detail in

118 section 2.3 below. However, the fact that in situ EGG ware samples have only been

119 recovered from colonial period archaeological contexts alongside other diagnostically

120 colonial period material culture makes the possibility that they were produced in

121 Prehispanic times highly unlikely.

122 The formal qualities of EGG Ware vessels and the archaeological contexts in

123 which they have been found suggest that indigenous peoples of Peru's North Coast

124 region were the type's primary producers and consumers. Of the 25 complete vessels

125 we have reviewed in museum collections, 13 have unmistakably Chimu-Inka forms. A

126 plurality (12) are double or multi-bodied whistling jars - a type common among Chimu

127 and Chimu-Inka mortuary assemblages that whistle when liquid is poured out of their

128 open spouts (Fig 2). One, held in the collection of the Peabody Museum of Archaeology

129 and Ethnology (Cambridge, MA, USA), is a Chimu-Inka stirrup spout bottle with a body

130 shaped like a deer. Nine of the remaining examples have strong similarities to

131 Prehispanic vessels - two bridge-spout bottles, two small pitchers with animal-like

132 mouths, four bottles with animal-shaped bodies, and one paccha (an Inka-style ritual

133 drinking vessel) shaped like a pacay (guava) fruit. 
134 The presence of non-traditional forms among EGG Ware vessels also suggests

135 that their creators were highly receptive to new designs. Three examples of EGG Ware

136 from museum collections are pitchers whose shapes have no Prehispanic precedents

137 and are therefore likely to have been modeled on Old World tablewares. Moreover,

138 while surface decoration (other than glaze) is rare among the 25 EGG Ware vessels we

139 have observed in museums, several contain low-relief molded decoration of cross

140 cutting vines and leaves - a design unknown among Prehispanic ceramics, which

141 Bushnell (1959) calls a "raised tree" motif.

142 These vessel forms and decorations raise the possibility that some EGG Ware

143 may have been consumed in non-indigenous households. However, as we discuss

144 below, all EGG Ware samples recovered to date from archaeological sites derive from

145 houses and middens with indigenous affiliations. It may be more likely that the

146 appearance of non-traditional forms among EGG Ware vessels reflects changing food

147 practices in indigenous households and a growing interest in new ceramic forms - a

148 pattern also reflected (albeit on different terms) in the increasing consumption of

149 imported tablewares within indigenous households in other regions of the Andes

150 (Jamieson, 2000; Rice, 2013, p. 156; Van Buren, 1993, pp. 309-316).

[Insert Figure 2]

152 Limited information on the provenance of complete EGG Ware vessels in

153 museum collections and fragments from colonial period archaeological sites provide an

154 outline of the contexts in which EGG Ware vessels were utilized and discarded. Based

155 on these patterns, it seems clear that the type was employed in both domestic and

156 mortuary settings and was produced during a short period of time in the mid to late $16^{\text {th }}$ 
157 Century. While only three whole vessels have been recovered in context, records point

158 to the area of the Pacific coastal plain located between the Lambayeque and Chao

159 valleys as the core region where EGG Ware was both produced and consumed. Rafael

160 Larco Hoyle's excavations at the "Playa de Chope" in the Chicama valley uncovered

161 two complete EGG Ware bottles in association with colonial period burials that also

162 contained glass beads, at a site whose primary period of occupation dates to Late

163 Prehispanic times (ML Cuaderno 3). At the site of Laguna de los Cóndores in the

164 Chachapoyas region of Peru, artifacts found alongside over two-hundred mummy

165 bundles included an EGG Ware double-spouted whistling bottle, as well as native

166 Chachapoyas and Inka pottery (Guillén, 2012). Museum records for two other EGG

167 Ware vessels suggest that one may have been extracted from a site in the Piura valley,

168 a second near the highland town of Recuay, and a third from the Huaura valley

169 (Bushnell, 1959). In isolated locations, where Spanish surveillance of indigenous

170 mortuary practices was limited, EGG Ware was incorporated into existing burial

171 traditions - perhaps relatively soon after the Spanish invasion of $1532 \mathrm{CE}$.

172 Excavations in contexts post-dating 1570 CE suggest that EGG Ware continued

173 to be produced after Peruvian Viceroy Francisco de Toledo's initiatives to forcibly

174 resettle indigenous people into planned towns called reducciones, carried out between

1751569 and 1575 CE (Toledo, 1986, 1867). At Magdalena de Cao Viejo (Chicama valley;

176 occupied ca. 1578-1720 CE) excavations recovered fragments of EGG Ware from

177 household features in the lowest, $16^{\text {th }}$ Century levels of the indigenous town, but not

178 from the site's church cloister, which was staffed by Dominican priests (Quilter, 2011;

179 VanValkenburgh, n.d.). At the site of Puerto Eten, Klaus and Alvarez-Calderón similarly 
180 recovered at least one fragment of EGG Ware from a household midden within a largely

181 indigenous town (personal communication, 2011). VanValkenburgh's (2012) survey and

182 excavations in the lower Zaña valley also recovered EGG Ware from domestic contexts

183 at two reducción sites founded in the late $16^{\text {th }}$ Century, Carrizales (C123) and Mocupe

184 Viejo (C74), as well as a colonial port occupied by indigenous people (the Port of

185 Chérrepe [C142]), a domestic site of unknown attribution (C216), and an isolated

186 mortuary site (C271). Excavations of looted contexts in the chapel at Carrizales (C123)

187 have recovered several large $(>5 \mathrm{~cm}$ diameter) fragments alongside dense

188 concentrations of recently looted human remains, fragments of provincial Inka

189 polychrome ceramics, and glass and shell beads, suggesting that at least some EGG

190 Ware was interred with the bodies of indigenous people in Christian contexts (Torres

191 Mora and VanValkenburgh, 2014).

192

$193 \quad 2.2$ Technological considerations in the production of EGG Ware

194 EGG Ware's unique combination of Andean ceramic forms with glazing has led

195 to speculation concerning the social contexts of its production. Several authors have

196 wagered that the indigenous potters who produced EGG Ware learned how to produced

197 glazes through direct instruction from Spanish ceramicists (Bushnell 1954; Mayer 1983;

198 Mogrovejo 1996). A corollary assumption is that EGG Ware was necessarily fired in

199 kilns, whose scarcity in Prehispanic times is often interpreted as a key factor for

200 explaining why ancient Andean potters never produced glazed ceramics, due to their

201 utility in sustaining the high temperatures necessary for complete vitrification of glazes

202 with relatively high melting points. Neither of these propositions has been systematically 
203 examined. Although full discussion of EGG Ware technology is beyond the scope of this

204 paper, the examination of technological indices on complete vessels provides clues

205 about production processes. To further investigate these questions, the first and second

206 author, along with colleague Karen Privat, are currently engaged in collaborative

207 research on EGG Ware firing conditions, through the use of refiring experiments and

208 scanning electron microscopy at the Mark Wainwright Analytical Centre, University of

209 New South Wales.

210 Among EGG Ware vessels held in museum collections and samples recovered

211 from archaeological excavations, one set of features consistently found on vessel

212 surfaces are aberrations that appear to be the results of the imperfect control of firing

213 temperatures. Crazing, crawling, pinholing, running and pooling are nearly ubiquitous

214 among all the samples we have investigated (Fig. 3). Moreover, vessel forms are often

215 visibly asymmetrical, with oblong bodies and spouts that sag to one side rather that

216 standing vertically (Fig 2). These defects provide evidence that the producers of EGG

217 Ware may have been experimenting with glaze compositions and/or firing conditions in

218 order to produce the lustrous effects they desired. According to the evidence we have

219 collected, EGG Ware production was never refined to remove these defects, and it may

220 have relied on indigenous methods such as bonfire firings. Historic documentation of

221 glazing technology among similar lead-glazed vessels from $16^{\text {th }}$-century highland

222 Mexico further suggests that glazes were produced using powdered galena, cerrusite or

223 other lead minerals applied directly to leather hard clay (a technique common in

224 medieval Europe) or ground and mixed in an aqueous solution painted onto leather-

225 hard clay (Lister and Lister, 1982, p. 81). 
228 2.3. Late Prehispanic Ceramic Production on Peru's North Coast and Colonial

229 Social Change

230 The style and technological characteristics of EGG Ware vessels raise questions

231 about the nature of the social and cultural contexts of their production. Their

232 preservation of Chimu-Inka forms suggests at least some continuity in ceramic traditions

233 between Late Prehispanic and Early Colonial times, if not in actual workshops. A

234 consideration of patterns of ceramic manufacture in Peru's North Coast region during

235 Late Prehispanic times provides a framework for interpreting how variation in paste and

236 glaze composition reflect the social organization of EGG Ware production.

237 Archaeologists working in the Lambayeque subregion of the North Coast have

238 argued that late Prehispanic ceramic production in that area was carried out at different

239 scales, from at least 900 CE. Beginning in Middle Sicán times (900-1100 CE), delicate

240 mold-made ceramics (many of them reduction-fired, high-luster blackwares) are found

241 alongside great numbers of coarser paddle-stamped earthenwares (paleteada) (Cleland

242 and Shimada, 1998, 1992; Kroeber and Muelle, 1942; Schaedel, 1979). Based on

243 excavations at the urban center of Batán Grande, Cleland and Shimada (1998) suggest

244 that there were three separate domains of ceramic production in Middle Sicán times: 1)

245 "attached" specialists producing sumptuary goods for exclusively elite consumption, on

246 a full-time basis; 2) specialists in independent workshops, partially overseen by elite

247 supervisors, producing goods for much broader consumption; 3) independent, part-time

248 producers of paddle-and-anvil ceramics displaying a dizzying array of decorative motifs 
249 (see also Tschauner, 2001, p. 34). While political and economic networks in the

250 Lambayeque region shifted during the course of subsequent centuries, following the

251 dominance of the Túcume polity during Late Sicán (1100-1350 CE) times and the

252 incorporation of the Lamabyeque region into the Chimu (ca. $1350 \mathrm{CE}$ ) and Inka (ca.

$2531470 \mathrm{CE}$ ) empires, discussions presume a broad division between the crafting of

254 sumptuary ceramics in supervised production centers and more socially and

255 geographically disperse crafting of paddle-stamped pottery, with its diversity of

256 decoration and composition.

$257 \quad$ Firing pits found at Chimu and Inka period ceramic production centers in the

258 Lambayeque region suggest that high luster blackwares were produced at a limited

259 number of specialized centers, where artisans had mastered reduction firing techniques

260 (Hayashida, 1999; Tschauner et al., 1994). Paddle-stamped wares were likely produced

261 in a greater number of locations, but early colonial documents suggest that ceramic

262 production was, like other crafts such as silversmithing and featherwork, still not

263 practiced in all households; rather, it was concentrated within specific residential

264 communities of olleros (Ramírez-Horton, 1982, 1981; Ramírez, 2007, 1996;

265 Rostworowski de Diez Canseco, 1977; Tschauner, 2001).

266 Excavations at several loci of ceramic production in Late Prehispanic sites

267 provide evidence that single communities of North Coast potters produced vessels of

268 multiple styles. Tschauner's (2001) excavations at the site of Pampa de los Burros, in

269 the Lambayeque valley, and Donnan's (1997) at an unnamed site near Cerro Cañoncillo

270 in the Jequetepeque valley uncovered both molds and paddles alongside one another

271 and ceramics of multiple different styles, including Inka polychrome. At Inka state- 
272 supervised facilities at La Viña and Tambo Real, Hayashida $(1999,1995)$ found

273 evidence for the parallel production of provincial Inka polychrome and local wares. In

274 these contexts, diversity in production may have arisen from the Inkas' resettlement of

275 artisans from diverse communities into roadside production centers.

276 Chimu-Inka vessels, which combine Inka forms with Chimu surface treatments or

277 Chimu forms with provincial Inka polychrome decoration, seem to have been produced

278 in similar contexts, where local ceramicists were challenged to fashion ceramics

279 suitable for Inka state rituals and diplomacy. Relatively little evidence for the production

280 of Chimu-Inka ceramics has been uncovered from archaeological contexts, but

281 Mackey's excavations within Inka precincts at the administrative center of Farfán, in the

282 Jequetepeque valley, recovered molds used for the production of Chimu-Inka style

283 pottery (Conrad, 1990; Mackey, 2010; Mackey and Jauregui, 2002). Such finds, as well

284 as the diversity and ubiquity of diverse "hybrid" Inka styles that combine the

285 characteristics of standardized Inka ceramic vessels with more localized traditions of

286 form and decoration (such as Ychma, Ica, and Chancay) suggests that they were not

287 necessarily the products of countercultural practices but may have been produced

288 largely in state-administered workshops (Costin, 2008).

289 Between the Spanish invasion of Peru in 1532 and the end of the $16^{\text {th }}$ century,

290 settlement, population, and craft production changed substantially in Peru's North Coast

291 region. As Inka control of the countryside dissipated, some specialized workshops were

292 abandoned. Epidemics of introduced Old World pathogens led to population loss of up

293 to $90 \%$ in some indigenous communities and an estimated $72 \%$ within the North Coast

294 region as a whole by the $17^{\text {th }}$ century (Cook, 1981; Ramírez-Horton, 1978). Native 
295 peoples continued to produce tribute for local leaders, but they redirected some surplus

296 toward Spanish encomenderos and ecclesiastical authorities, and they incorporated

297 new goods into tributary lists, including Old World cultigens (Ramírez, 1996). Spanish

298 settlements were founded at Piura (1532), Trujillo (1535), and Zaña (1563). While

299 viceroy Toledo's reducción policy was intended to insulate indigenous populations from

300 wider colonial society, it is likely that at least some indigenous people (particularly

301 muleteers and traders) were frequent visitors to Spanish settlements (Ramírez, 1986;

302 VanValkenburgh, 2012). The organization of ceramic production in and around these

303 new urban centers is poorly understood, but a court case against an ollero (potter) in

304 Trujillo in1614 demonstrates that there was at least one specialized producer operating

305 in that city by the early $17^{\text {th }}$ century (ART Corregimiento 166/572). In our view, however,

306 the presence of EGG Ware and paddle-stamped ceramics in late $16^{\text {th }}$ century sites

307 occupied by indigenous people outline a separate sphere of production.

308 While the fact that EGG Ware continued to employ Chimu-Inka forms signals

309 continuity in some elements of Prehispanic traditions, only data on its composition and

310 construction can begin tell us more about how its production was organized in the

311 colonial period. We hypothesize that if EGG Ware was produced in one or a very small

312 number of specialized workshops each using a limited number of sources and recipes

313 throughout their duration, then paste composition should form a limited number of

314 groups, across samples collected from sites in multiple regions. In contrast, if its

315 production was more dispersed, involving less specialization and supervision and/or

316 using multiple raw sources and recipes, then pastes should be compositionally diverse.

317 We also hypothesize that the restricted knowledge required to identify suitable raw 
318 materials for glaze production (i.e., lead ores), possible restricted access to such

319 materials, and the specialized knowledge of how to prepare and bind glazes to vessels,

320 should lead to glaze composition being a less sensitive marker of the loci of EGG Ware

321 ceramic production than paste composition.

\section{$323 \quad 2.4$ The sample collection}

The samples characterized here derive from excavations and systematic surface

325 collections at sites in two valleys within Peru's North Coast region, Zaña and Chicama

326 (see Fig 1). Twenty-five samples were recovered from sites in the Zaña valley - 11 from

327 VanValkenburgh's excavations and survey at the site of Mocupe Viejo (C74), eight from

328 excavations and survey at the site of Carrizales (C123), three from survey at an isolated

329 mortuary site (C271), two from a small midden associated with a colonial period canal

330 (C216), and one from the Colonial Port of Chérrepe (C142) (Figure 4). In the Chicama

331 valley, all 18 samples derive from Quilter's excavations at Magdalena de Cao Viejo -

332 specifically, the lowest levels of occupation in the site's town sector.

333

334

335

336

337 references, it is clear that Mocupe Viejo and Carrizales were both reducciones

338 established some time between 1566 and 1573 CE (VanValkenburgh, Walker and

339 Sturm, 2014). Carrizales (C123), where stratigraphy is shallow and the ceramic

340 assemblage is limited to late $16^{\text {th }}$ century material (including Panama Plain ceramics, 
341 but no fragments of Panama Polychrome or Panama Blue-on-White), seems to have

342 been occupied for a very brief period of time - no longer than three decades. EGG

343 Ware samples from Carrizales were recovered from middens closely associated with

344 wattle-and-daub (quincha) domestic structures. In contrast, Mocupe Viejo was not

345 abandoned until 1652, when its residents moved up-valley to avoid dunes encroaching

346 on their residences and to have greater access to fresh water.

347 EGG Ware samples from Mocupe Viejo were recovered both from the town

348 sector and a midden adjacent to the town's chapel. Excavations revealed high levels of

349 deflation at the site, leading its materials to be highly accessible for surface collection

350 but challenging definition of how its occupation changed over time. Here, the presence

351 of late $16^{\text {th }}$ century through mid $17^{\text {th }}$ century ceramic assemblages, as well as historical

352 records tightly date the site's abandonment in 1652 CE, (BNL A310; AGN Ucupe 30:

353 26r-26v; VanValkenburgh, 2012). The port of Chérrepe, established circa 1563,

354 contains a small ( 3.5 hectare) colonial settlement occupied until the end of the $18^{\text {th }}$

355 century. The single EGG Ware fragment recovered at the site derived from a looted

356 area. Fragments from Conjunto 271 were recovered from the surface of a sandy terrace

357 raised 5-10 meters above surrounding agricultural fields, alongside fragmented human

358 remains and Late Preshispanic materials associated with nearby looters' holes.

359 Samples from Conjunto 216 were collected from the surface of a small $(1.27 \mathrm{Ha})$ site,

360 with occupation estimated to date from the late $16^{\text {th }}$ through mid $17^{\text {th }}$ centuries (based

361 on ceramic typology), closely associated with a colonial period canal system.

362 Quilter's (2011) excavations at the site of Magdalena de Cao Viejo suggest that

363 the town was founded in C.E. 1578 after an El Niño flood, and abandoned sometime in 
364 the early to mid- $18^{\text {th }}$ century C.E. (Castañeda Murga, 1996). Eighteen EGG Ware

365 sherds were recovered from the lowest levels of the site's domestic areas, from trash

366 areas within three separate household structures. These occupations appear to be late

$36716^{\text {th }}$ century in date, based on the absence of material culture typical of mid-1 $7^{\text {th }}$ century

368 assemblages in archaeological sites within the North coast of Peru.

369 Due to the scarcity of EGG Ware samples recovered in archaeological contexts,

370 the majority of samples studied here are small body sherds. Each was selected from

371 widely separated excavation contexts in order to reduce the possibility of obtaining

372 multiple samples from the same vessel. Samples 02-48, 209-12, and MDC2011-36-03

373 are rim sherds from small bottles, while 40-019 and 123-30-01 appear to derive from the

374 necks of bottles with diameters of less than $5 \mathrm{~cm}$. Sample $05-19$ represents the base of

375 a flat-bottomed vessel. Each of these types falls within the range of Chimu-Inka forms.

376 In contrast, samples 684-01 (a rim sherd pictured at far left in figure 4) and 44-023 (a

377 handle fragment) appear to derive from pitchers with no Chimu-Inka precedents. The

378 remaining samples all have glaze applied only to a single, external surface. Surface

379 forms range from flat to highly convex - suggesting pitchers, bottles, and serving jars

380 rather than plates or storage and cooking vessels.

381 Across the sample collection, glaze color is variable both between and within

382 samples, as is visible in Figure 4. We estimate that color variation within vessels is in

383 part the product of the uneven application of glaze material before firing, as well as

384 running, pooling, and variation in firing temperatures. Four samples (05-019, 40-019,

385 MDC2011-00-02, and MDC2011-46-08) have glaze that is more matted and yellow in

386 appearance, but each also shows signs of surface wear, suggesting that these color 
387 differences may be more closely related with patterns of use and deposition rather than 388 chemical composition.

In sum, the EGG Ware samples studied here derive from a narrow chronological

390 range (50 to 75 years) and a broad geographical area (approximately 100 kilometers

391 along the Peruvian coast), allowing productive comparisons across time and space. By

392 the standards of previous studies of ceramic composition, the total sample size

393 discussed here $(n=43)$ is relatively small. However, it represents virtually all of the EGG

394 Ware fragments recovered via systematic archaeological excavation and survey to date

395 and offers an opportunity for initial characterization of chemical variation in the type.

\section{3. Methods}

398 The pastes and glazes of 43 samples were analyzed using two analytical

399 techniques: instrumental neutron activation analysis (INAA) to characterize pastes and

400 laser-ablation-inductively coupled plasma-mass spectrometry (LA-ICP-MS) to

401 characterize sample glazes.

\section{$404 \quad 3.1$ Instrumental neutron activation analysis (INAA)}

405 Specimens were prepared for INAA using procedures established at the

406 Archaeometry Laboratory, University of Missouri Research Reactor (MURR) (Glascock,

407 1992; Glascock and Neff, 2003). Fragments of approximately $1 \mathrm{~cm}^{2}$ were removed from

408 each sherd and abraded using a silicon carbide burr in order to remove surface

409 treatments and adhering soil, to reduce the risk of contamination. The specimens were 
410 washed in deionized water and allowed to dry in the laboratory. Once dry, the individual

411 fragments were ground to powder in an agate mortar. Samples were then prepared as

412 detailed by Glascock and Neff, along with certified reference materials from National

413 Institute of Standards and Technology (NIST) (SRM-1633b (coal fly ash), SRM-688

414 (basalt rock) and SRM-278 (obsidian rock) and in-house standard, Ohio Red Clay.

415 Procedures used for the irradiation and gamma ray spectroscopy follow

416 established MURR Archaeometry Laboratory protocol (Glascock, 1992; Glascock and

417 Neff, 2003; Neff, 2000). A total of 32 element concentrations were determined: Al, Ba,

$418 \mathrm{Ca}, \mathrm{Dy}, \mathrm{K}, \mathrm{Mn}, \mathrm{Na}, \mathrm{Ti}, \mathrm{V}, \mathrm{La}, \mathrm{Lu}, \mathrm{Nd}, \mathrm{Sm}, \mathrm{U}, \mathrm{Yb}, \mathrm{Ce}, \mathrm{Co}, \mathrm{Cr}, \mathrm{Cs}, \mathrm{Eu}, \mathrm{Fe}, \mathrm{Hf}, \mathrm{Ni}, \mathrm{Rb}, \mathrm{Sb}$,

419 Sc, Sr, Ta, Tb, Th, Zn and Zr.

420

$421 \quad$ 3.2. LA-ICP-MS

422 The analyses were carried out at the Field Museum of Natural History in

423 Chicago, USA, using an Analytik Jena Inductively Coupled Plasma - Mass

424 Spectrometer (ICP-MS) connected to a New Wave UP213 laser for direct introduction of 425 solid samples.

426 Helium was used as a gas carrier in the laser, and scan line analysis mode was

427 selected. To clean the surface of the glaze, a pre-ablation was conducted with a laser

428 beam diameter of $100 \mu \mathrm{m}$, a speed of $70 \mu \mathrm{m} / \mathrm{s}$ and at a pulse frequency of $20 \mathrm{~Hz}$. The

429 laser beam diameter for the actual ablation was $65 \mu \mathrm{m}$. It was used with a speed of 5

$430 \mu \mathrm{m} / \mathrm{s}$ and a frequency of $15 \mathrm{~Hz}$. For each glaze sample, the average of four

431 measurements corrected from the blank was considered for the calculation of

432 concentrations. 
The isotope Si29 was used for internal standardization. Concentrations for major

434 elements, including silica, were calculated assuming that the sum of their

435 concentrations in weight percent in glass is equal to $100 \%$ (Gratuze, 1999).

436 Two different series of external standards were used to measure major, minor and trace

437 elements. The first series of external standards are standard reference materials (SRM)

438 manufactured by NIST: SRM 610 and SRM 612. Both of these standards are soda-lime-

439 silica glass doped with trace elements in the range of $500 \mathrm{ppm}$ (SRM 610) and $50 \mathrm{ppm}$

440 (SRM 612). A total of 48 element concentrations were determined: Li, Be, B, Sc, Ti, V,

$441 \mathrm{Cr}, \mathrm{Fe}, \mathrm{Mn}, \mathrm{Ni}, \mathrm{Co}, \mathrm{Cu}, \mathrm{Zn}, \mathrm{As}, \mathrm{Rb}, \mathrm{Sr}, \mathrm{Zr}, \mathrm{Nb}, \mathrm{Ag}, \mathrm{In}, \mathrm{Sn}, \mathrm{Sb}, \mathrm{Cs}, \mathrm{Ba}, \mathrm{La}, \mathrm{Ce}, \mathrm{Pr}, \mathrm{Ta}$,

$442 \mathrm{Au}, \mathrm{Y}, \mathrm{Pb}, \mathrm{Bi}, \mathrm{U}, \mathrm{W}, \mathrm{Mo}, \mathrm{Nd}, \mathrm{Sm}, \mathrm{Eu}, \mathrm{Gd}, \mathrm{Tb}, \mathrm{Dy}, \mathrm{Ho}, \mathrm{Er}, \mathrm{Tm}, \mathrm{Yb}, \mathrm{Lu}, \mathrm{Hf}$, Th. For

443 additional details, see procedures outlined in Dussubieux et al. 2009.

444

\section{3.3. Data Interpretation}

446 For both datasets (INAA and LA-ICP-MS) principal components analysis (PCA)

447 was carried out on chemical data. In the analysis of INAA data, Ni and Sb were

448 excluded, as Ni was below detection level for most specimens, and Sb could be a

449 potential glaze contaminant. Discrimination of chemical groups was also determined

450 through the analysis of elemental biplots and the mean and standard deviations for

451 groups. PCA using all of the remaining elements determined by INAA failed to provide

452 much discrimination of the Zaña and Chicama valley groups, possibly due to the fact

453 that some elements were acting as noise in the dataset, effectively obscuring patterns in

454 the dataset pertaining to region. Such situations in statistical analysis have been

455 discussed by Michelaki and Glascock (2011) Michelaki, Hughes and Hancock (2013), 
456 and Baxter and Jackson (2001), who discuss eliminating variables/elements from PCA.

457 In our study, this led to the analysis of datasets comprised of $21,12,11$, eight, six and

458 four elements, with elements for use in PCA determined by the study of biplots and

459 means and standard deviations for each element in each valley group. Ultimately, PCA

460 using eight elements ( $\mathrm{Nd}, \mathrm{Sm}, \mathrm{U}, \mathrm{Co}, \mathrm{Eu}, \mathrm{Sr}, \mathrm{Tb}, \mathrm{Ca})$ provided the clearest chemical

461 separation between the Zaña and Chicama valley groups (presented here). Log10-

462 transformed data and centred log-ratio (CLR) transformed data (presented here) were

463 used, with both providing similar group discrimination.

464 In addition to excluding PB, we also excluded $\mathrm{Zn}, \mathrm{As}, \mathrm{Ag}, \mathrm{In}, \mathrm{Sb}$ and $\mathrm{Bi}$ in our

465 statistical analysis of the LA-ICP-MS data, due to high variability in these elements'

466 concentrations and their tendency to associate with lead. Although one would expect

467 that the inclusion of these elements in statistical analyses would allow for good

468 discrimination of groups if different lead sources were used, we found that high

469 variability in their concentrations obscured patterns in the data. It is possible that the

470 lead ores used to produce glazes in our samples have high source variability in trace

471 element composition and/or that some aspect of firing, such as volitilization, has

472 affected these elements. One of us (LD) has encountered similar elemental variability in

473 the analysis of glasses with high lead content.

$474 \quad$ Gold $(\mathrm{Au})$ was excluded due to low concentrations and detection limits and $\mathrm{Pb}$

475 constituted the major component of most glazes (up to $80 \%$ ), potentially swamping

476 patterns in the data. PCA and elemental bivariate plots were used to determine

477 chemical groupings. Statistical analyses were performed using Statistica (v7.0), MURR 
478 GAUSS routines (v.8) and Microsoft Excel 2007, with JMP (v.10.0.0) used to create

479 figures.

480

481 4. Results

482 4.1. INAA

483 Table 1 presents the results of INAA of the EGG Ware pastes. Based on PCA of 484 eight elements described above, the first three principal components (PCs) accounted 485 for $92.7 \%$ variability in the dataset. Figure 5 presents the plot of the first three PCs and 486 associated loadings plot. The separation of the Zaña and Chicama valley sherds is due 487 to significant contribution on PC1 from $\mathrm{Ca}, \mathrm{Sr}$ and $\mathrm{Co}$, generally higher in the Zaña 488 samples. One subgroup of samples from Magdalena de Cao (consisting of samples 489 MDC2011-130-18, MDC2011-29-09, MDC2011-130-16, MDC2011-14-04, MDC2011490 30-34-03, MDC2011-30-12, MDC2011-31-14, MDC2011-36-03, MDC2011-54-05, 491 MDC2011-00-02, MDC2011-00-01) also groups with sample 29-42, from the Zaña 492 valley. SJK 199 and 201 are loosely associated with this groups though and SJK201 493 might be an outlier but definitely distinct from other Zaña valley samples. A loose 494 subgroup appears in this cluster, consisting of samples MDC2011-130-16, MDC2011495 14-04, MDC2011-31-14, and MDC2011-54-05 Of the Chicama valley samples, 496 MDC2011-126-13 and MDC2011-00-07 are outliers. MDC2011-10-11 and MDC2011-

497 46-08 associate with the Zaña samples, and MDC2011-00-06 and MDC2011-130-18 498 may form a loose group with Zaña sherd 684-001. However, more samples are needed 499 for this series of samples to be called a group, and they currently appear to be outliers. 
In contrast, the Zaña samples present as a scatter, with no discernible groups

501 within the sample set. No grouping can be discerned according to the samples' sites of

502 recovery, although they appear generally chemically distinct from the Chicama Valley

503 sherds - with the exception of those Zaña sherds described above. More samples might

504 be required to discern groups within the Zaña dataset.

505

[Insert Table 1]

506

[Insert Figure 5]

\section{4.2. LA-ICP-MS}

508 PCA of data resulting from LA-ICP-MS of EGG Ware glazes shows a distinct

509 separation of samples from the Chicama valley and sites in the Zaña Valley. PCA of the

510 first 7 PCs account for $89.2 \%$ of variation in the dataset. Figure 6 shows the plot of the

511 first two PCs and the associated loadings plot.

512

[Insert Table 2]

513

[Insert Figure 6]

514 Of the Chicama valley samples, MDC2011-46-08, MDC54-05 and MDC2011-

515 126-13 appear to be outliers in the analysis of data obtained by LA-ICP-MS, associated

516 with neither other Chicama valley nor Zaña valley samples. Similarly, Zaña valley

517 samples 586-12, 586-22, 29-42, 5-14 and 74-2-42 are also outliers. The two former

518 samples have much higher Sn concentrations than any of the other samples from either

519 valley. Chicama valley sample MDC2011-00-07 appears to be associated with Zaña

520 valley samples although in the statistical analyses of the data resulting from INAA, this

521 sample is an outlier. Further comparing these results with those based on the analysis

522 of data obtained by INAA, the fabrics of MDC2011-126-13, MDC2011-46-08 and 
523 MDC2011-10-11 are outliers, although the latter two seem to have a chemical similarity

524 to Zaña samples. Of these only the two former are also outliers in the analysis of data

525 obtained from LA-ICP-MS of the glazes. The sample MDC2011-00-06 glaze groups with

526 other glazes from Magdalena de Cao, whereas the fabrics appear to be outliers based

527 on analysis of data obtained by INAA.

528

\section{5. Discussion}

\section{$530 \quad 5.1$ Interpretation of Chemical Data}

531 The two characterization techniques applied here yielded contrasting patterns of

532 chemical association in EGG Ware samples in part because each probes different

533 aspects of pottery production - namely, the creation of the ceramic paste and glazing.

534 Analysis of the glazes indicates that they were primarily composed of lead ore and

535 points to clear differences in raw materials used for glaze production in the Zaña and

536 Chicama valleys. This pattern may imply that access to lead ore and its preparation

537 before application to vessels was specific to each valley. The greater scatter of the

538 Zaña Valley samples may also point to the use of multiple sources of lead ore, the

539 exploitation of more heterogeneous ore deposits or combinations of materials in glaze

540 recipes, as compared with the rather tighter cluster of samples from the Chicama valley.

541 It is possible that different firing conditions, especially firing temperatures, fuel, and

542 soaking times, could also contribute to compositional variation, especially in the analysis

543 of glazes encountered here - for example, through volatilization. Finally, the scatters

544 observed in the Zaña dataset could also be related to the limited number of samples ( $\mathrm{n}$

$545=25)$ collected from five sites, as well as changes in production over time at each site. 
546 Future compositional analyses of EGG Ware would greatly benefit from expanded

547 access to samples, procured through additional excavations at colonial period

548 archaeological sites on Peru's North Coast.

549 Analysis of our INAA data suggests that there was a high level of diversity in the

550 composition of pastes amongst Zaña valley samples. This pattern is possibly linked to

551 the limited number of samples obtained from five distinct sites, but also likely indicates a

552 larger number of workshops produced the vessels - and/or that a greater variety of

553 materials and recipes were present among Zaña valley EGG Ware producers. Although

554 compositional diversity also exists among the pastes of samples from Magdalena de

555 Cao, the existence of a major cluster within the data suggests that a subset of the

556 Chicama valley samples may have derived from a single source.

557 Some paste composition outliers among the materials from the Chicama valley

558 are chemically similar to samples from the Zaña valley, but none form a definitive

559 chemical group that crosscuts both regions based on INAA analysis of pastes. The

560 outliers identified during the analysis of data on pastes obtained by INAA of samples

561 from the Chicama valley are sometimes reflected in outliers identified in the analysis of

562 data on glazes obtained by LA-ICP-MS. Some, such as MDC2011-126-13, might

563 indicate both vessel production and glazing occurred outside of sources that contributed

564 to the other Chicama samples and majority of the Zaña Valley scatter. The association

565 of Zaña Valley sample 29-42 paste with the main Chicama valley chemical paste group

566 suggests the same source for the body of the vessel, but glazing using different

567 materials to other Chicama valley samples. 


\subsection{Inferring EGG Ware Production Patterns}

570 We interpret these compositional patterns, as well as the formal characteristics of

571 EGG Ware vessels, as evidence that the type was fashioned not in one or two

572 workshops but in a diverse (and likely geographically disperse) series of loci. While we

573 cannot rule out the possibility that some EGG Ware may have been produced by non-

574 indigenous ceramicists or consumed by non-indigenous peoples, the archaeological

575 contexts in which EGG Ware has been discovered, as well as its conservation of

576 Chimu-Inka ceramic forms, imply that it was primarily used and produced by people

577 indigenous to Peru's north coast region.

578 EGG Ware's characteristics also suggest that it was the product of indigenous

579 ceramicists' sustained engagement with novel ceramic traditions - an openness to

580 innovation that is also reflected in the deeper history of Chimu-Inka ceramics in

581 Prehispanic times. Flat-bottomed pitchers, represented both among our samples and

582 among museum collections, as well as raised surface decoration in the form of vines

583 and vegetation, show that EGG Ware potters were receptive to new forms. While

584 indigenous people were socially marginalized within the North Coast region, many lived

585 in close proximity to Spanish colonial urban centers, frequently interacted with broader

586 colonial society, and consumed the products of non-indigenous ceramic workshops,

587 including tin-enameled tablewares and lead-glazed storage vessels (Torres Mora, 2011;

588 VanValkenburgh, 2012, n.d.). Indigenous consumption of foreign glazed ceramics, as

589 well as interaction with Spanish colonial craftspeople (if not their direct observation of

590 the production of glazed ceramics in Spanish colonial workshops) was surely integral to

591 EGG Ware's creation. 
Yet compositional diversity among our sample pastes suggests that the

593 ceramicists who produced EGG Ware were not concentrated in a small number of

594 workshops directly supervised by Spanish artisans. Based on our results, the

595 organization of EGG Ware's production would appear to resemble less the tightly

596 controlled production of provincial Inka polychrome and more the dispersed production

597 of paddle-stamped ceramics, which have dominated domestic assemblages in the

598 Lambayeque region since $900 \mathrm{CE}$.

599 These results frame a series of questions that should be addressed through

600 further exploration of samples from archaeological sites and museum collections: What

601 specific sources of lead ore were exploited to produce EGG Ware glazes, and how were

602 these sources identified? Are further compositional groups discernable in EGG ware

603 deposited in site in the Zaña and Chicama valleys? How extensively was EGG Ware

604 moved between valleys? Are continuities observable between EGG Ware and

605 Prehispanic paste groupings? Both chemical studies and petrological analysis should

606 be conducted to address these questions as more EGG Ware samples become

607 available.

608

609

610 6. Conclusions

611 The chemical composition of 43 samples of EGG Ware, determined via INAA of

612 pastes and LA-ICP-MS of glazes, suggest that the type's pastes were produced by

613 multiple workshops using a diversity of recipes and/or raw materials and a slightly more

614 restricted series of glaze materials and possible recipes/preparation. Observed 
615 compositional diversity in both pastes and glazes is higher among the sample of 25

616 samples from sites in the Zaña valley, than among the 15 samples from the site of

617 Magdalena de Cao Viejo, in the Chicama valley. Compared to paste composition, less

618 diversity is present among glaze composition, which falls into two groups that correlate

619 broadly with the Zaña valley and Magdalena de Cao Viejo sample sets, respectively -

620 perhaps reflecting the use of distinct lead ore sources and/or preparation in each valley

621 for the production of EGG Ware glazes.

622 Our analysis represents a study of nearly the entire set of EGG Ware samples

623 recovered from archaeological contexts to date. As additional sites are excavated and

624 greater numbers of EGG Ware fragments are recovered, further compositional study

625 and lead isotope analysis of glazes will allow us to further test the patterns described

626 here. Comparison of EGG Ware paste composition with that of Prehispanic Chimu-Inka

627 materials will enable us to study substantial relationships between Prehispanic and

628 colonial workshops and better understand the effects of colonial political change on craft

629 and artistic practice.

630

631

632

633

634

635

636

637

638

639

640

641

642

643

644

645

\section{Acknowledgements}

Funding for the ICP-MS analysis was provided with the support of an NSF major instrumentation grant to the Analytical Research Facility at the Field Museum (BCS 0818401). INAA analysis was funded by the University of Vermont and through subvention from the National Science Foundation to the University of Missouri Research Reactor (Grant 1415403). Funding for the excavations and field research that recovered samples was provided through an International Dissertation Research Fellowship from the Social Science Research Council (to VanValkenburgh) and a National Endowment for the Humanities Collaborative Research Grant (RZ5115010, to Quilter). Cody Roush provided analytical assistance at MURR. Scott Van Keuren provided helpful comments on an earlier draft of this paper. Ulla Holmquist and Isabel Collazos at the Museo Larco Herrera provided support in the examination of complete vessels and access to Rafael Larco Hoyle's excavation notes. We also thank Ryan Williams, Matthew Piscitelli, 
646 Cristian Mesia Montenegro, Regulo Franco Jordan, Carmen Gamarra Carol Rojas

647 Vega, Rocio Torres Mora, and Rosabella Alvarez-Calderón.

\section{Archival Sources - Abbreviations}

AGN - Archivo General de la Nación, Lima, Peru

ART - Archivo Regional de Trujillo, Peru

BNL - Biblioteca Nacional, Lima, Peru

ML - Museo Rafael Larco Herrera, Lima, Peru

\section{References}

Acevedo Basurto, S., Torres, F., Alayza, P.P., 2004. La loza de la tierra: cerámica vidriada en el Perú. Universidad Ricardo Palma, Lima.

Acevedo, S., 1986. Trayectoría de la cerámica vidriada en el Perú, in: Stastny, F., Acevedo, Sara (Eds.), Vidriados Y Mayólica Del Perú. Museo de Arte y de Historia, Universidad Nacional Mayor de San Marcos, Lima, Peru, pp. 19-31.

Bushnell, G., 1959. Some Post-Columbian Whistling Jars from Peru. Actas Del XXXIII Congreso Internacional de Americanistas, 416-420.

Castañeda Murga, J., 1996. Permanecer tras el desastre: la ciudad de Saña después de los Niños de 1578 y 1720. Rev. Archaeobios 4, 85-95.

Cleland, K.M., Shimada, I., 1998. Paleteada Potters: Technology, Production Sphere, and Sub-Culture in Ancient Peru. MASCA Res. Pap. Sci. Archaeol. 15, 111-152.

Cleland, K.M., Shimada, I., 1992. Sicán bottles: Marking time in the Peruvian bronze age. Andean Past 3, 193-235.

Conrad, G., 1990. Farfán, General Pacatnamú, and the Dynastic History of Chimor. North. Dynast. Kingship Statecraft Chimor Michael E Mosely Alana Cordy-Collins Eds 227-242.

Cook, N.D., 1981. Demographic collapse, Indian Peru, 1520-1620, Cambridge Latin American studies $\square$; 41. Cambridge University Press, Cambridge.

Costin, C.L., 2008. Material Symbols of Status, Class, and Power in the Inka Empire. Presentation at the Society for American Archaeology Annual Meeting, Vancouver, BC, Canada.

Donnan, C.B., 1997. A Chimu-Inka ceramic-manufacturing center from the north coast of Peru. Lat. Am. Antiq. 30-54.

Fenn, T.R., Mills, B.J., Hopkins, M., 2006. The social contexts of glaze paint ceramic production and consumption in the Silver Creek area. Status Publ.

Glascock, M.D., 1992. Characterization of archaeological ceramics at MURR by neutron activation analysis and multivariate statistics, in: Neff, H.H. (Ed.), Chemical Characterization of Ceramic Pastes in Archaeology. Prehistory Press, Madison, Wis., pp. 11-26. 
692

693

694

695

696

697

698

699

700

701

702

703

704

705

706

707

708

709

710

711

712

713

714

715

716

717

718

719

720

721

722

723

724

725

726

727

728

729

730

731

732

733

734

735

736
Glascock, M.D., Neff, H., 2003. Neutron activation analysis and provenance research in archaeology. Meas. Sci. Technol. 14, 1516-1526.

Guillén, S.E., 2012. De Chinchorro a Chiribaya: los ancestros de los mallquis Chachapoya-Inca. Bol. Arqueol. PUCP 287-303.

Habicht-Mauche, J.A., 2006. The social history of the Southwestern Glaze Wares, 1250-1680, in: Habicht-Mauche, J.A., Eckert, S.L., Huntley, D.L. (Eds.), The Social Life of Pots: Glaze Wares and Cultural Dynamics in the Southwest, AD. University of Arizona Press, Tucson, pp. 3-16.

Hayashida, F.M., 1999. Style, technology, and state production: Inka pottery manufacture in the Leche Valley, Peru. Lat. Am. Antiq. 337-352.

Hayashida, F.M., 1995. State pottery production in the Inka provinces. Unpublished Ph.D. Dissertation, University of Michigan.

Hecker, W., Hecker, G., 1988. Baessler-Archiv: Keramik des späten Horizontes und der frühen Kolonialzeit aus der Region des unteren Jequetepeque-Tales, Nordperuanische Küste. Baessler-Arch. XXXVI, 149-252.

Herhahn, C.L., 2006. Inferring social interactions from pottery recipes: Rio Grande glaze paint composition and cultural transmission. Soc. Life Pots Glaze Wares Cult. Dyn. Southwest AD 1250-1680 Univ. Ariz. Press Tucson 179-196.

Jamieson, R.W., 2000. Domestic architecture and power $\square$ : the historical archaeology of colonial Ecuador, Contributions to global historical archaeology. Kluwer Academic/Plenum Publishers, New York.

Kroeber, A.L., Muelle, J.C., 1942. Cerámica paleteada de Lambayeque. Rev. Mus. Nac. Lima 1, 1-24.

Lister, F.C., Lister, R.H., 1982. Sixteenth Century Maiolica Pottery in the Valley of Mexico. University of Arizona Press, Tucson.

Mackey, C.J., 2010. The Socioeconomic and Ideological Transformation of Farfán under Inka Rule, in: Malpass, M., Alconini, S. (Eds.), Distant Provinces in the Inka Empire: Toward a Deeper Understanding of Inka Imperialism. University Of lowa Press, lowa City, p. 221-259.

Mackey, C.J., Jauregui, C., 2002. Proyecto Arqueológico de Farfan. Informe Preliminar (Archaeological Research Report). Instituto Nacional de Cultura, Lima, Peru.

Mayer, E.F., 1984. Frühkoloniale "Chimú"-Keramik von der peruanischen Nordküste. Beitr. Zur Allg. Vgl. Archäol. 5, 431.

Mogrovejo Rosales, J.D., 1996. Arqueologia urbana de evidencias coloniales en la ciudad de Lima, Cuadernos de Investigación. Pontificia Universidad Católica del Perú, Instituto Riva-Agüero, Lima.

Neff, H., 2003. Analysis of Mesoamerican plumbate pottery surfaces by laser ablationinductively coupled plasma-mass spectrometry (LA-ICP-MS). J. Archaeol. Sci. $30,21-35$.

Neff, H., 2000. Neutron activation analysis for provenance determination in archaeology, in: Ciliberto, E., Spoto, G. (Eds.), Modern Analytical Methods in Art and Archaeology. John Wiley and Sons, New York, pp. 81-134.

Neff, H., Bishop, R.L., 1988. Plumbate origins and development. Am. Antiq. 505-522. Quilter, J., 2011. Cultural encounters at Magdalena de Cao Viejo in the early colonial period, in: Liebmann, M., Murphy, M.S. (Eds.), Enduring Conquests: Rethinking 
the Archaeology of Resistance to Spanish Colonialism in the Americas. School of Advanced Research Press, Santa Fe, pp. 103-126.

Ramírez-Horton, S.E., 1982. Retainers of the lords or merchants: a case of mistaken identity? El Hombre Su Ambiente En Los Andes Cent., Senri Ethnological Studies 10, 123-136.

Ramírez-Horton, S.E., 1981. La organización económica de la costa norte: un análisis preliminar del período prehispánico tardío, in: Castelli, A., Koth de Paredes, M., Mould de Pease, M. (Eds.), Etnohistoria Y Antropología Andina, Jornada Del Museo Nacional de Historia. Museo Nacional de Historia, Lima, pp. 281-297. Ramírez-Horton, S.E., 1978. Chérrepe en 1572: Un Analisis de la Visita General del Virrey Francisco de Toledo. Hist. Cult. 11, 79-121.

Ramírez, S.E., 2007. It's All in a Day's Work: Occupational Specialization on the Peruvian North Coast, Revisited, in: Shimada, Izumi (Ed.), Craft Production in Complex Societies $\square$ : Multicraft and Producer Perspectives, Foundations of Archaeological Inquiry. University of Utah Press, Salt Lake City, pp. 262-280.

Ramírez, S.E., 1996. The world upside down $\square$ : cross-cultural contact and conflict in sixteenth-century Peru. Stanford University Press, Stanford, Calif.

Ramírez, S.E., 1986. Provincial patriarchs $\square$ : land tenure and the economics of power in colonial Peru, 1st ed. University of New Mexico Press, Albuquerque.

Rice, P.M., 2013. Space-Time Perspectives on Early Colonial Moquegua. University Press of Colorado, Boulder, CO.

Rice, P.M., 1987. Pottery analysis: a sourcebook. University of Chicago Press, Chicago

Rostworowski de Diez Canseco, M., 1977. Coastal fishermen, merchants, and artisans in pre-Hispanic Peru, in: Benson, E.P. (Ed.), The Sea in the Pre-Columbian World. Dumbarton Oaks Research Library and Collections, Washington, D.C., pp. 167-186.

Schaedel, R.P., 1979. The Confluence of the Pressed Ware and Paddle Ware Traditions in Coastal Peru. Collect. Anthr. 21, 231-239.

Shepard, A.O., 1948. Plumbate, a Mesoamerican trade ware. Carnegie Institution of Washington, Washington, D.C.

Toledo, F. de, 1986. Francisco de Toledo: disposiciones gubernativas para el Virreinato del Perú, Publicaciones de la Escuela de Estudios Hispano-Americanos de la Universidad de Sevilla. Escuela de Estudios Hispano-Americanos, Seville, Spain. Toledo, F. de, 1867. Relaciones de los vireyes y audiencias que han gobernado el Perú. Imprenta del estado por J. E. del Campo, Lima.

Torres Mora, R., 2011. Cerámica colonial en el valle bajo y medio de Zaña: tecnología, formas y comercio (Licenciatura). Pontificia Universidad Catolica del Peru, Lima, Peru.

Torres Mora, R., VanValkenburgh, P., 2014. Excavaciones en el Sitio de Carrizales (LA057), Temporada 2014 (Informe Técnico). Ministerio Nacional de Cultura (Peru).

Tschauner, H., 2001. Socioeconomic and political organization in the late Prehispanic Lambayeque Sphere, northern North Coast of Peru. Harvard University.

Tschauner, H.W., Vetters, M., Dulanto, J., Saco C., M., Wester la Torre, C., 1994. Un taller alfarero Chimú en el valle de Lambayeque. Tecnología y organización de la producción de cerámica prehispánica en los Andes., in: Shimada, I. (Ed.), Tecnología Y Organización de La Producion Cerámica Prehispánica En Los 

Andes. Fondo Editorial, Pontificia Universidad Católica del Perú, Lima, pp. 349_ 394.

Tschopik, H., 1950. An Andean ceramic tradition in historical perspective. Am. Antiq. 15, 196-218.

Van Buren, M., 1993. Community and empire in Southern Peru: the site of Torata Alta under Spanish rule (Unpublished Ph.D. Dissertation). University of Arizona, Tucson.

Van Keuren, S., 2006. Decorating Glaze-Painted Pottery in East-Central Arizona, in: Habicht-Mauche, J.A., Eckert, S.L., Huntley, D.L. (Eds.), The Social Life of Pots: Glaze Wares And Cultural Dynamics in the Southwest, Ad 1250-1680. Unviersity of Arizona Press, Tucson, pp. 86-104.

Van Keuren, S., Neff, H., Agostini, M.R., 2013. Glaze-paints, technological knowledge, and ceramic specialization in the fourteenth-century Pueblo Southwest. J. Anthropol. Archaeol. 32, 675-690.

VanValkenburgh, P., 2012. Buliding Subjects: Landscapes of Forced Resettlement in the Zaña and Chamán Valleys, Peru, 16th-17th Centuries C.E. (Unpublished Ph.D. Dissertation). Harvard University, Cambridge, MA.

VanValkenburgh, P., n.d. Consumption and Commerce at Magdalena de Cao Through the Lens of Ceramic Analysis, in: Quilter, J. (Ed.), Magdalena de Cao Viejo: An Archaeology of Colonial Life in Northern Peru. Peabody Museum Press, Harvard University, Cambridge, MA. 


\begin{tabular}{|c|c|c|c|c|c|c|c|c|c|c|}
\hline Sample ID & Valley & Site & As & La & Lu & Nd & Sm & U & Yb & $\mathrm{Ce}$ \\
\hline $123-30-001$ & Zaña & Conjunto 123 (Carrizales) & 4.1 & 40.7 & 0.4 & 30.8 & 6.0 & 3.5 & 3.1 & 85.9 \\
\hline $123-9-019$ & Zaña & Conjunto 123 (Carrizales) & 3.4 & 36.8 & 0.4 & 34.0 & 6.7 & 4.4 & 2.7 & 72.5 \\
\hline 139-039 & Zaña & Conjunto 74 (Mocupe Viejo) & 6.1 & 27.6 & 0.3 & 19.4 & 4.3 & 3.3 & 2.0 & 49.6 \\
\hline 139-041 & Zaña & Conjunto 74 (Mocupe Viejo) & 8.5 & 33.2 & 0.4 & 32.4 & 6.8 & 2.6 & 2.5 & 73.5 \\
\hline $187-009$ & Zaña & Conjunto 123 (Carrizales) & 3.3 & 36.0 & 0.4 & 27.8 & 5.3 & 3.2 & 2.6 & 67.8 \\
\hline $209-012$ & Zaña & Conjunto 123 (Carrizales) & 3.7 & 46.7 & 0.5 & 40.5 & 7.5 & 3.7 & 2.9 & 90.3 \\
\hline $209-014$ & Zaña & Conjunto 123 (Carrizales) & 2.2 & 45.5 & 0.4 & 35.7 & 7.2 & 4.1 & 3.2 & 86.9 \\
\hline $219-013$ & Zaña & Conjunto 142 (Port of Chérrepe) & 3.4 & 31.6 & 0.2 & 22.5 & 4.9 & 2.7 & 1.4 & 62.0 \\
\hline $219-014$ & Zaña & Conjunto 142 (Port of Chérrepe) & 3.4 & 30.9 & 0.2 & 23.5 & 4.8 & 2.4 & 1.4 & 70.2 \\
\hline $245-014$ & Zaña & Conjunto 123 (Carrizales) & 11.4 & 33.7 & 0.3 & 21.8 & 4.9 & 4.0 & 1.9 & 62.5 \\
\hline $25-013$ & Zaña & Conjunto 74 (Mocupe Viejo) & 5.6 & 37.1 & 0.4 & 28.4 & 5.8 & 3.5 & 3.0 & 71.4 \\
\hline $29-042$ & Zaña & Conjunto 271 & 4.4 & 60.3 & 0.7 & 50.6 & 10.6 & 6.8 & 4.4 & 124.9 \\
\hline $395-001$ & Zaña & Conjunto 216 & 4.0 & 40.1 & 0.3 & 26.4 & 5.6 & 2.4 & 2.2 & 73.2 \\
\hline 40-019 & Zaña & Conjunto 74 (Mocupe Viejo) & 8.0 & 42.7 & 0.5 & 38.9 & 7.5 & 3.5 & 2.8 & 90.0 \\
\hline $44-023$ & Zaña & Conjunto 74 (Mocupe Viejo) & 6.3 & 34.5 & 0.4 & 28.9 & 5.8 & 2.9 & 2.5 & 73.1 \\
\hline $5-014$ & Zaña & Conjunto 74 (Mocupe Viejo) & 5.6 & 57.1 & 0.6 & 47.2 & 9.4 & 5.1 & 3.9 & 119.1 \\
\hline $5-058$ & Zaña & Conjunto 74 (Mocupe Viejo) & 3.5 & 37.7 & 0.4 & 33.8 & 6.7 & 3.1 & 3.0 & 74.2 \\
\hline & Zaña & & 4.0 & 41.5 & 0.4 & & 7.4 & 2.9 & 2.8 & 87.1 \\
\hline $586-012$ & Zaña & Conjunto 271 & 5.8 & 33.9 & 0.4 & 27.6 & 5.5 & 2.6 & 2.7 & 69.9 \\
\hline $586-022$ & Zaña & Conjunto 271 & 4.4 & 28.5 & 0.3 & 20.4 & 4.3 & 3.1 & 1.8 & 56.1 \\
\hline $684-001$ & Zaña & Conjunto 123 (Carrizales) & & & 0.5 & & 7.8 & 5.4 & 3.6 & 103.9 \\
\hline $72-019$ & Zaña & Conjunto 74 (Mocupe Viejo) & 11.7 & 35.7 & 0.3 & 24.9 & 5.1 & 3.0 & 2.1 & 71.4 \\
\hline $74-7-004$ & Zaña & Conjunto 74 (Mocupe Viejo) & 4.2 & 49.1 & 0.6 & 41.8 & 8.4 & 3.9 & 3.7 & 101.6 \\
\hline $74-9-042$ & Zaña & Conjunto 74 (Mocupe Viejo) & 12.2 & 40.2 & 0.3 & 28.3 & 5.8 & 4.5 & 2.0 & 73.8 \\
\hline $74-9-016$ & Zaña & Conjunto 74 (Mocupe Viejo) & 9.5 & 29.1 & 0.2 & 25.7 & 4.6 & 2.2 & 1.4 & 74.1 \\
\hline MDC2011-00-01 & Chicama & Madalena de Cao Viejo & 8.1 & 53.4 & 0.6 & 46.1 & 10.7 & 4.5 & 4.4 & 118.2 \\
\hline MDC2011-00-02 & Chicama & Madalena de Cao Viejo & 2.3 & 56.5 & 0.5 & 43.9 & 9.4 & 5.6 & 3.4 & 117.7 \\
\hline MDC2011-00-06 & Chicama & Madalena de Cao Viejo & 7.3 & 43.6 & 0.5 & 33.7 & 6.4 & 4.0 & 3.4 & 89.5 \\
\hline MDC2011-00-07 & Chicama & Madalena de Cao Viejo & 4.5 & 52.4 & 0.5 & & 8.3 & 4.0 & 3.4 & 105.8 \\
\hline MDC2011-10-11 & Chicama & Madalena de Cao Viejo & 2.4 & 35.1 & 0.4 & 28.0 & 5.2 & 2.9 & 2.6 & 69.6 \\
\hline MDC2011-126-13 & Chicama & Madalena de Cao Viejo & 17.3 & 24.1 & 0.4 & 21.5 & 5.0 & 2.5 & 2.5 & 52.3 \\
\hline MDC2011-130-16 & Chicama & Madalena de Cao Viejo & 3.9 & 45.6 & 0.5 & 40.2 & 7.9 & 4.6 & 2.8 & 93.5 \\
\hline MDC2011-130-17 & Chicama & Madalena de Cao Viejo & 5.5 & 63.9 & 0.6 & 52.4 & 10.1 & 5.1 & 4.1 & 143.5 \\
\hline MDC2011-14-04 & Chicama & Madalena de Cao Viejo & 4.7 & 51.9 & 0.5 & 45.6 & 9.4 & 5.0 & 3.7 & 110.4 \\
\hline MDC2011-29-09 & Chicama & Madalena de Cao Viejo & 3.7 & 64.4 & 0.7 & 61.2 & 11.1 & 7.2 & 4.3 & 140.3 \\
\hline MDC2011-29-10 & Chicama & Madalena de Cao Viejo & 4.4 & 61.9 & 0.6 & 54.1 & 10.8 & 6.5 & 4.2 & 138.4 \\
\hline MDC2011-30-12 & Chicama & Madalena de Cao Viejo & 3.8 & 63.2 & 0.7 & 57.4 & 10.9 & 6.9 & 4.3 & 140.7 \\
\hline MDC2011-30-15 & Chicama & Madalena de Cao Viejo & 4.0 & 60.2 & 0.6 & 51.3 & 10.3 & 6.0 & 4.2 & 135.6 \\
\hline MDC2011-30-34-3 & Chicama & Madalena de Cao Viejo & 4.1 & 62.9 & 0.6 & 52.5 & 10.8 & 7.1 & 4.8 & 136.5 \\
\hline MDC2011-31-14 & Chicama & Madalena de Cao Viejo & 3.3 & 53.2 & 0.5 & 45.1 & 8.0 & 5.0 & 3.4 & 123.5 \\
\hline MDC2011-36-03 & Chicama & Madalena de Cao Viejo & 4.1 & 62.8 & 0.6 & 57.1 & 10.8 & 7.3 & 4.2 & 137.6 \\
\hline MDC2011-46-08 & Chicama & Madalena de Cao Viejo & 1.5 & 34.9 & 0.4 & 25.3 & 5.1 & 2.7 & 2.5 & 69.8 \\
\hline MDC2011-54-05 & Chicama & Madalena de Cao Viejo & 4.3 & 55.1 & 0.6 & 47.8 & 8.5 & 5.5 & 4.0 & 114.4 \\
\hline
\end{tabular}




\begin{tabular}{|c|c|c|c|c|c|c|c|}
\hline Sample ID & Valley & Site & Si & $\mathrm{Na}$ & Mg & Al & $\mathbf{K}$ \\
\hline $123-30-001$ & Zaña & Conjunto 123 (Carrizales) & 55846.2 & 1718.8 & 844.4 & 16739.2 & 2610.5 \\
\hline $123-9-019$ & Zaña & Conjunto 123 (Carrizales) & 64770.1 & 1026.8 & 1114.2 & 21826.4 & 3417.2 \\
\hline 139-039 & Zaña & Conjunto 74 (Mocupe Viejo) & 54353.9 & 347.3 & 604.8 & 14866.1 & 1330.6 \\
\hline $139-041$ & Zaña & Conjunto 74 (Mocupe Viejo) & 77920.9 & 667.9 & 1303.7 & 28087.2 & 3655.2 \\
\hline $187-023$ & Zaña & Conjunto 123 (Carrizales) & 109370 & 1111.1 & 1576.7 & 27814.4 & 4490.5 \\
\hline $209-012$ & Zaña & Conjunto 123 (Carrizales) & 50625.3 & 514.2 & 983.8 & 17667.8 & 3128.8 \\
\hline $209-014$ & Zaña & Conjunto 123 (Carrizales) & 93906.8 & 727.9 & 1589.2 & 33029.6 & 4801.8 \\
\hline $219-013$ & Zaña & ınjunto 142 (Port of Chérrer & 100635.4 & 4118.3 & 3293.9 & 36868.2 & 6123.3 \\
\hline $245-014$ & Zaña & Conjunto 123 (Carrizales) & 97496.8 & 1049 & 2060.4 & 32918.6 & 4560.4 \\
\hline $25-013$ & Zaña & Conjunto 74 (Mocupe Viejo) & 57062.9 & 594.6 & 1212.2 & 15528.5 & 2386.2 \\
\hline $29-042$ & Zaña & Conjunto 271 & 72553.1 & 1021.3 & 1058 & 25469.6 & 2302.8 \\
\hline $395-001$ & Zaña & Conjunto 216 & 101012.5 & 6303.1 & 2554.1 & 35428.2 & 8438 \\
\hline $395-001$ & Zaña & ınjunto 142 (Port of Chérrep & 98534.1 & 3203.4 & 3183.5 & 32007.2 & 6922.8 \\
\hline $40-019$ & Zaña & Conjunto 74 (Mocupe Viejo) & 47412.4 & 1147.1 & 787.4 & 17383.5 & 5178.1 \\
\hline $44-023$ & Zaña & Conjunto 74 (Mocupe Viejo) & 49790.3 & 586.4 & 813.8 & 15585.9 & 3918.7 \\
\hline $5-014$ & Zaña & Conjunto 74 (Mocupe Viejo) & 105128.1 & 1777.8 & 1548.3 & 43259.9 & 14172.8 \\
\hline $5-058$ & Zaña & Conjunto 74 (Mocupe Viejo) & 77765.7 & 2239.9 & 1201.6 & 24819.8 & 6947.9 \\
\hline $586-010$ & Zaña & Conjunto 271 & 56451.9 & 464 & 576.6 & 13761.2 & 1493.9 \\
\hline $586-012$ & Zaña & Conjunto 271 & 62684 & 246.4 & 859.7 & 11560.3 & 2224.8 \\
\hline $586-022$ & Zaña & Conjunto 271 & 67354.8 & 1461.9 & 932.2 & 17420.3 & 3392.4 \\
\hline $684-001$ & Zaña & Conjunto 123 (Carrizales) & 57955.8 & 528.3 & 1225.7 & 21121 & 3361.8 \\
\hline 72-019 & Zaña & Conjunto 74 (Mocupe Viejo) & 94182.5 & 1364.1 & 1894.2 & 29670 & 4137.1 \\
\hline 74-7-004 & Zaña & Conjunto 74 (Mocupe Viejo) & 68931.7 & 1091.4 & 850.8 & 23866.3 & 3362.8 \\
\hline $74-9-016$ & Zaña & Conjunto 74 (Mocupe Viejo) & 69647.1 & 1724.4 & 913.9 & 24115 & 2237.3 \\
\hline 74-9-042 & Zaña & Conjunto 74 (Mocupe Viejo) & 77411.2 & 755.1 & 1184.3 & 37854.7 & 1685.8 \\
\hline MDC2011-00-01 & Chicama & Magdalena de Cao Viejo & 81726.4 & 150.2 & 3823.7 & 50617.4 & 4062 \\
\hline MDC2011-00-02 & Chicama & Magdalena de Cao Viejo & 59872.9 & 644.9 & 2456 & 28668.6 & 4091.9 \\
\hline MDC2011-00-06 & Chicama & Magdalena de Cao Viejo & 86717.9 & 143.2 & 1679.7 & 33917.1 & 1517.2 \\
\hline MDC2011-00-07 & Chicama & Magdalena de Cao Viejo & 52515 & 623.2 & 1878.4 & 20746.4 & 2406.1 \\
\hline MDC2011-10-11 & Chicama & Magdalena de Cao Viejo & 82143 & 1012 & 3384.2 & 23998.2 & 3774.1 \\
\hline MDC2011-126-13 & Chicama & Magdalena de Cao Viejo & 141046.5 & 5982.1 & 17732.1 & 55582.2 & 10651.9 \\
\hline MDC2011-130-16 & Chicama & Magdalena de Cao Viejo & 63696.3 & 143.5 & 1985.3 & 26744.9 & 1929.2 \\
\hline MDC2011-130-17 & Chicama & Magdalena de Cao Viejo & 83820.5 & 351.4 & 2791.9 & 38432.3 & 4408.8 \\
\hline MDC2011-14-04 & Chicama & Magdalena de Cao Viejo & 73967.5 & 97.6 & 2362.4 & 29406.1 & 2158.6 \\
\hline MDC2011-29-09 & Chicama & Magdalena de Cao Viejo & 58577.1 & 571.2 & 1908.4 & 21229.9 & 4155.5 \\
\hline MDC2011-29-10 & Chicama & Magdalena de Cao Viejo & 83157.3 & 307.3 & 3092.4 & 33848.3 & 4729.5 \\
\hline MDC2011-30-12 & Chicama & Magdalena de Cao Viejo & 69714.9 & 133.1 & 2359.8 & 27638.2 & 2465.8 \\
\hline MDC2011-30-15 & Chicama & Magdalena de Cao Viejo & 77809.1 & 420.6 & 3020.6 & 35441 & 5896.1 \\
\hline MDC2011-30-34-3 & Chicama & Magdalena de Cao Viejo & 69403.9 & 442.4 & 2320.1 & 27893.3 & 4161.8 \\
\hline MDC2011-31-14 & Chicama & Magdalena de Cao Viejo & 89476.2 & 526.6 & 2983.1 & 37255.9 & 2292.2 \\
\hline MDC2011-36-03 & Chicama & Magdalena de Cao Viejo & 75408 & 216.8 & 2455.7 & 27585.1 & 3623.8 \\
\hline MDC2011-46-08 & Chicama & Magdalena de Cao Viejo & 139464.3 & 1350 & 5661 & 37967.6 & 6616.1 \\
\hline MDC2011-54-05 & Chicama & Magdalena de Cao Viejo & 117837.9 & 1802 & 4955.6 & 32964.3 & 6818.2 \\
\hline
\end{tabular}




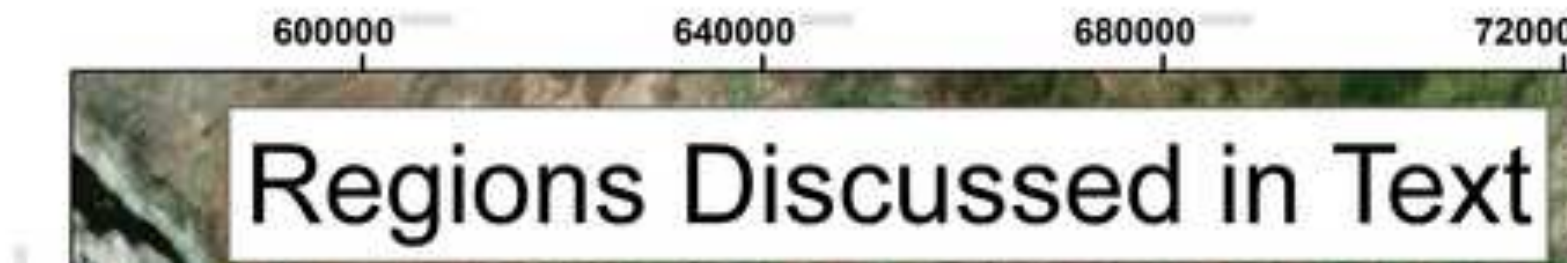

Lower Zaña Valley

응

(details in Fig. 3)

ठั.

Piura Valley

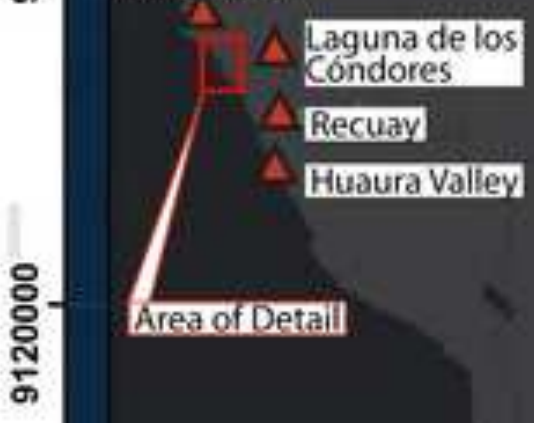

chiletayd

응

웅

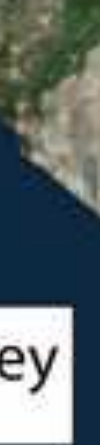

aring

\section{Lower Chicama Valley}

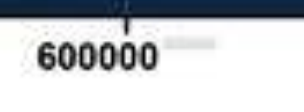



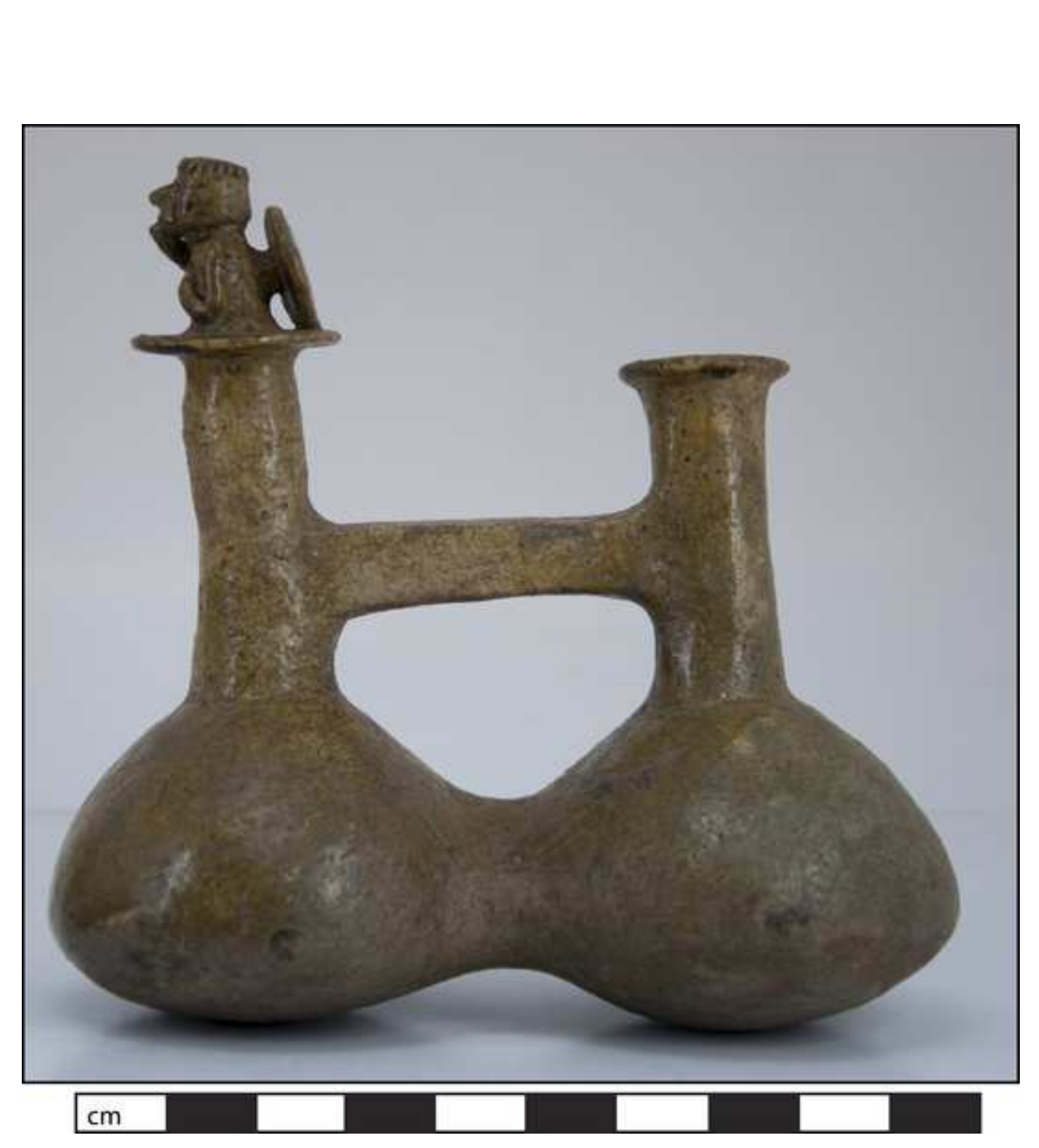

Figure 2

Figure 2

2

.

(20)

I
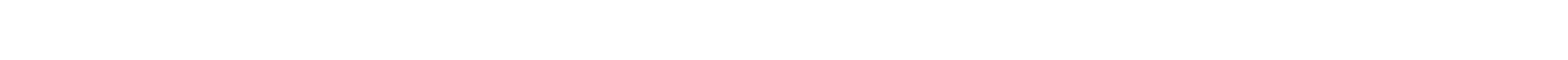


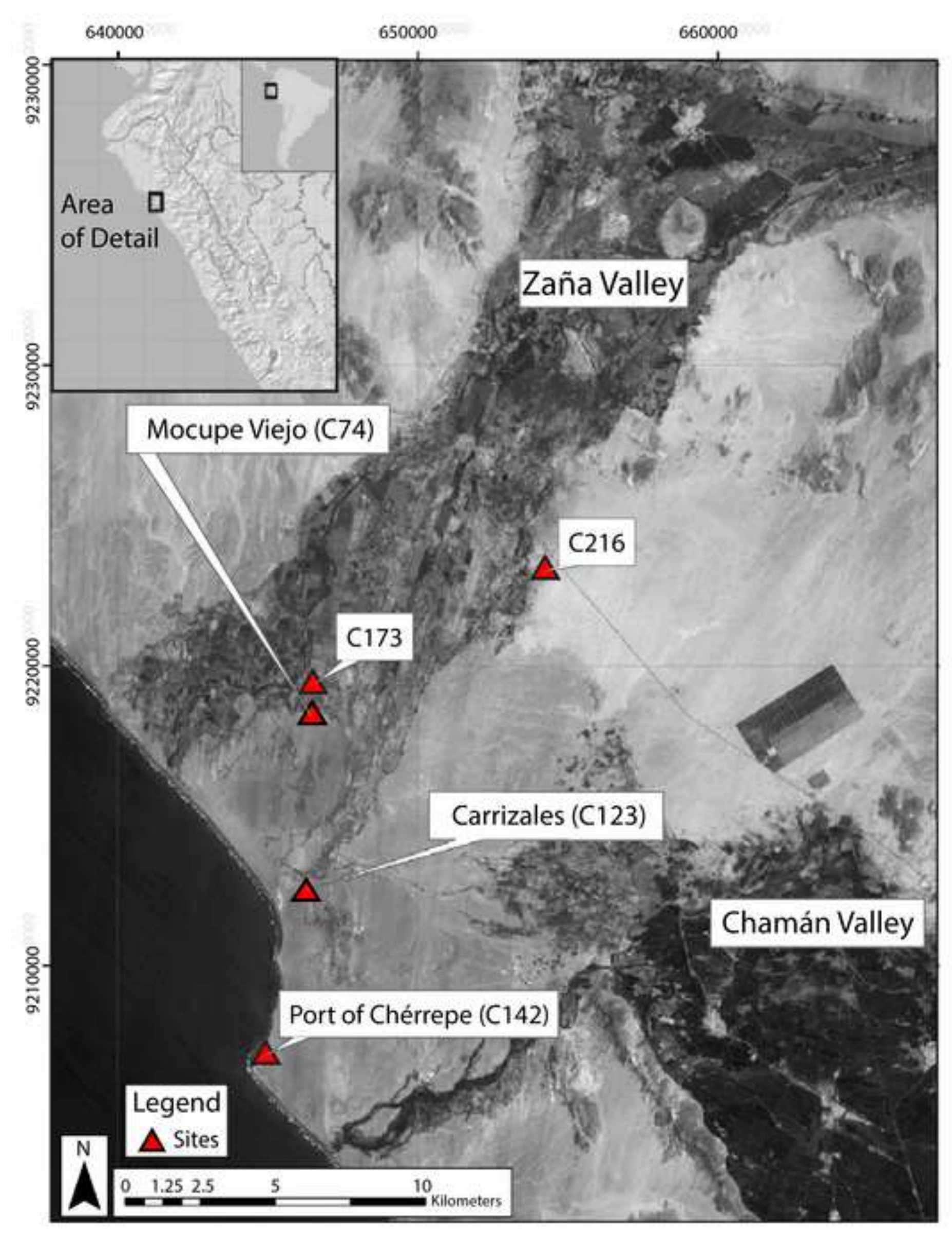

\section{Fir}

\section{3}

.

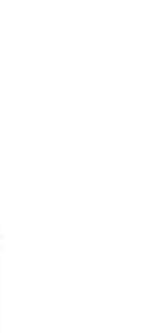



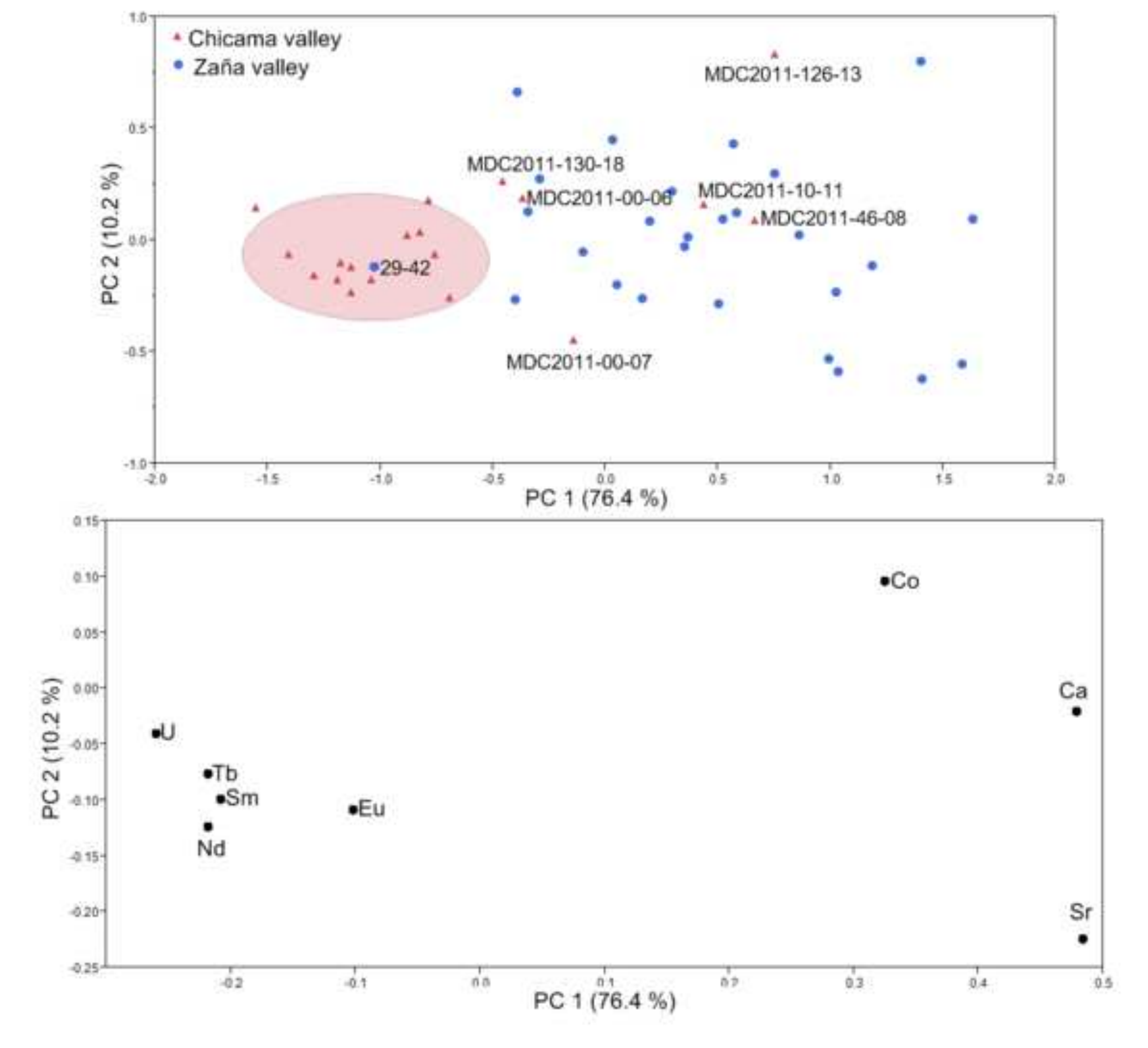

Figure

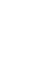

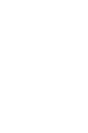



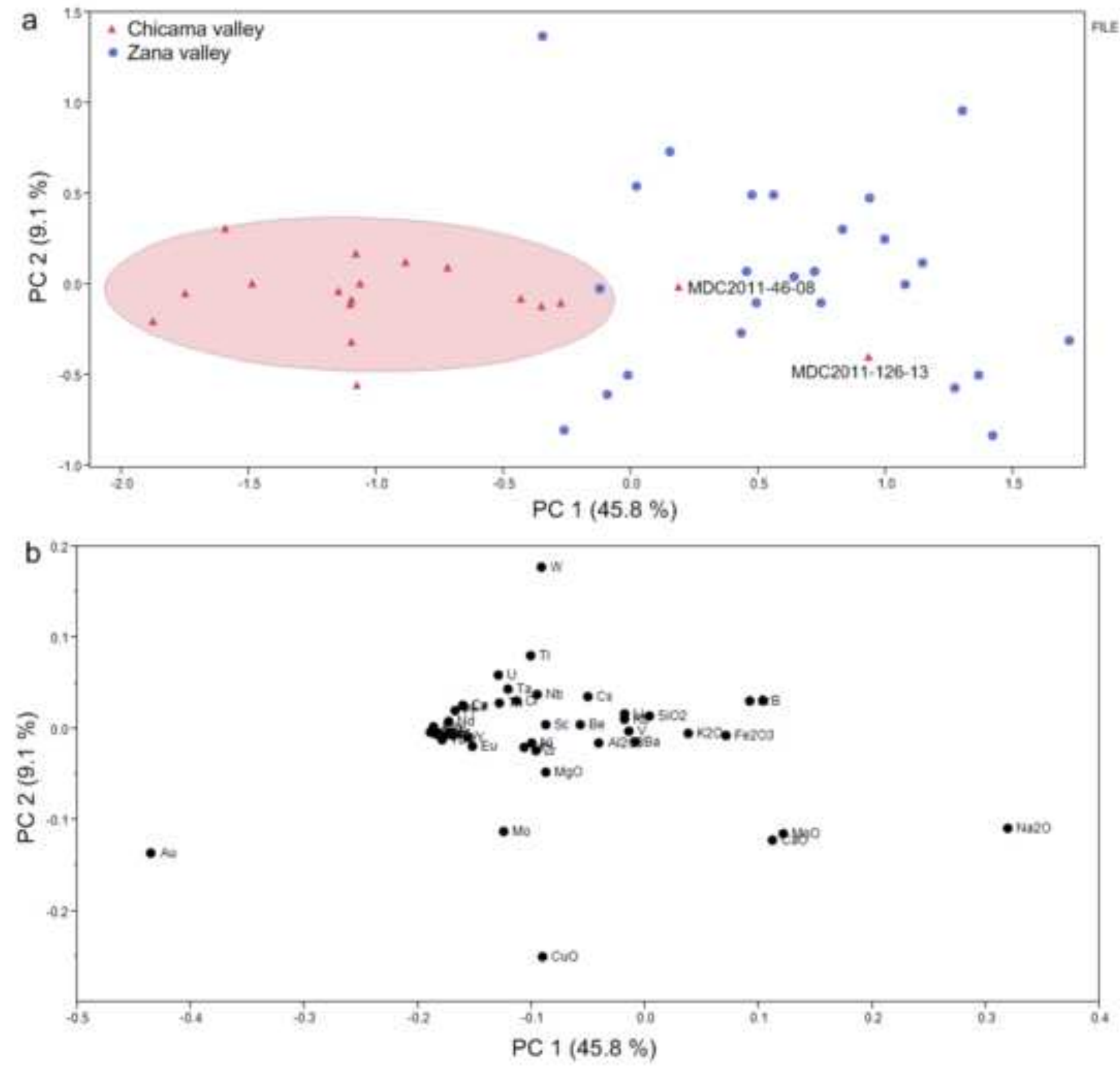
Figure 1 - Regions and sites discussed in text.

(BW in print; Color digital)

Figure 2 - EGG Ware double-bodied whistling vessel, adorned with a figure playing an instrument, perhaps an ocarina (Catalog number ML017537). Image courtesy of the Museo Arqueológico Rafael Larco Herrera.

(BW in print; Color digital)

Figure 3 - Regional map of archaeological sites in the Zaña valley from which EGG ware samples were collected. The base image is a processed ASTER Image captured in 2007, courtesy of NASA.

(BW in print; Color digital)

Figure 4 - Close-up photographs of EGG Ware samples collected in Peru's Zaña valley. Samples 684-01, 245-014, and 123-30-1

(BW in print; Color digital)

Figure 5 - Principal Components analysis of INAA data from EGG ware sample pastes.

(BW in print; Color digital)

Figure 6 - Principal Components analysis of LA-ICP-MS data from EGG ware sample glazes.

(BW in print; Color digital)

Table 1 - INAA data from samples

Table 2 - LA-ICP-MS data from samples 